\title{
THE MUTUAL BENCHMARKING METHOD FOR SMES' COMPETITIVE STRATEGY DEVELOPMENT
}

\author{
Katarzyna ROSTEK \\ Warsaw University of Technology, Faculty of Management, Warsaw, Poland \\ e-mail: k.rostek@wz.pw.edu.pl
}

\begin{abstract}
Competitive advantage is a relative feature, evaluated in respect of other competing enterprises. The gaining of sustainable competitive advantage is conditioned by knowledge of own performance and the results of the competitive environment. SMEs have limited opportunities to obtain such information on their own. The method of mutual benchmarking changes this situation by introducing the collaborative network. The aim of the cooperation is to support each of the group members to achieve sustainable competitive advantage, which is the result of a conscious strategy, and not only a matter of chance. This cooperation is based on the collecting and processing of data and sharing information through a common IT platform: for example, a group of Polish SMEs was shown how to implement such a common IT solution and how to provide the information preparing within the proposed service. The whole is a complete proposal for effective support of creating a competitive strategy in SMEs.
\end{abstract}

Keywords: competitiveness, competitive position, competitive analysis, competitive strategy, mutual benchmarking, SME sector.

\section{Introduction}

In today's economy, a variety of entities (countries, regions, cities, sectors, industries, clusters, enterprises, groups of people, individuals) compete in the local and international markets for access to objects of rivalry (such as customers, resources, products, services, capital, knowledge, work, power, position, prestige and many others) [Pettigrew, 1988; Porter, 19902011]. Due to the large span of the competitiveness concept, being precise about its definition is extremely difficult and it is still an object of research [Balkyte \& Tvaronavičiene, 2010; Cellino \& Soci, 2012].

In this paper, the definition of competition as the company's ability to design, produce and sell products and services for which demand is greater than corresponding products and services offered by their competitors has been accepted [Porter, 1998; Ajitabh $\&$ Momaya, 2004]. Such an understanding of competition is considered to be the most important mechanism from the economic point of view, by which promoting the most favourable solutions triggers the creativity of rival market entities, which in turn leads to the development of the economy and improvement of the living conditions of the whole population [Begg, 1999; Garengo, et al., 2005; Porter, 2011; Magretta, 2011].

This creativity, understood as business innovation, has a decisive impact on the competitive advantage in the market [Porter, 1990-2011; Gunday, et al., 2011].
The measure of this advantage is the competitive position, defined always in relation to the positions held by the competitors [Porter, 1980-1985; Moon \& Newman, 1995]. According to the researchers [Feurer \& Chaharbaghi, 1994; D'Aveni, 2010], improving the competitiveness of a company means a move for a better, a more favourable competitive position. Realisation of this goal requires determining in which of the business functions (such as sales, marketing, production, logistics, personnel management, research and development) the company is able to achieve a competitive advantage and what value of the competitive position it would like to get in a defined time. This in turn requires knowing the results of the functioning of the company and its competitors in terms of:

- the results of business operations, which allows its activity to be compared with the activities of other players in the market and learning through the use of best practises,

- the values of competitiveness determinants, which enables the strengths and weaknesses of the enterprise and the potential areas of competitive advantage to be identified,

- assessing the own competitive position in relation to the position occupied by the competitors in the current state of the market.

Acquiring this information requires access to the data documented by the results of business activities of other competitors on the market, and then collecting 
and processing them into the form of an accessible, understandable and useful analytical report. For this purpose, it is necessary to use advanced information technology from group analysis and reporting systems, like Business Intelligence (BI). As shown by conducted research [Lee, et al., 2010; Rostek, 2010; Zeng, et al., 2010], the typical SME company is not able to meet these requirements, because its competitiveness potential, conditioned and limited by available resources, is not sufficient.

The author's concept of mutual benchmarking services, following the world trends in the development of competitiveness [Brandenburger, et al., 1998; Cellino \& Soci, 2012], refers to the etymology of the word competitiveness (Lat. concurrere, cum petere), which means the common search, performing or striving for the same goal, i.e. achieving and maintaining the company's assumed competitive position.

This understanding of the concept of competitiveness allows certain forms of cooperation in the framework of the competitive market, whose different variants are known and described in the literature under the name of collaboration network [Malecki \& Tootle, 1996; Rosenfeld, 1996; Bernal, et al., 2002; Kingsley \& Malecki, 2004; Zeng, et al., 2010].

In the benchmarking mutual service the cooperation network is established to strengthen the competitive potential of a group of companies to a level allowing the information necessary to achieve a sustainable competitive advantage by the participants to be obtained.

The concept of this service is presented in this paper in the following sections. Section 2 presents the research question, main target and hypothesis of the research work. Section 3 describes the research methods and tools used in the work. In Section 4, the benchmarking method is presented in the context of its use in the competitive analysis. Section 5 contains the author's concept of the method of mutual benchmarking. A case of the use of this method in Polish SME dental clinics is given in Section 6. Discussion of the results obtained and directions for further research are presented in Section 7.

\section{Research objective}

As is apparent from the research of the SME sector in Poland [Rostek, 2010; Bilińska-Reformat, 2011; Dziekoński, 2011], people managing these companies make decisions based primarily on their own knowledge and experience (approximately 90\% cases, [Rostek, 2010]). Nearly $40 \%$ of respondents declare using analysis and reports in the management process, and even fewer, about $20 \%$ of the respondents use specialised tools to support decision-making [Rostek, 2010]. The only analysis and reporting IT solutions used in the surveyed companies are Microsoft Excel and StatSoft Statistica Package Base [Rostek, 2010]. This situation results from the specifics of the SME sector in Poland and is associated with a lack of appropriate potential in the following:

- knowledge and experience of the implementation of competitive analysis and using its results to create a competitive strategy,

- financial, technical, human and organisational resources necessary for the implementation of IT solutions supporting the advanced competitive analysis,

- qualified staff responsible for the handling, maintenance and development of IT solutions, ensuring the implementation of competitive analysis, development and distribution of results reports,

- the number of generated and collected data resources, which are the power source for competitive analysis.

This results in insufficient use of the available information and knowledge in the management of competitiveness. Meanwhile, SMEs need to deal not only with the competitive advantage of large companies, but also with the competition from each other, so the truth becomes the statement of Comarch representatives, that: "small business needs the same as large, but faster, better and cheaper". On this basis it is possible to formulate a research question:

RQ: What methods and resources can provide SMEs with access to the knowledge that will ensure that a sustainable competitive advantage can be obtained?

\footnotetext{
${ }^{1}$ Series of Comarch conferences organized for the SMEs in nine Polish cities on 6-16 November 2007.
} 


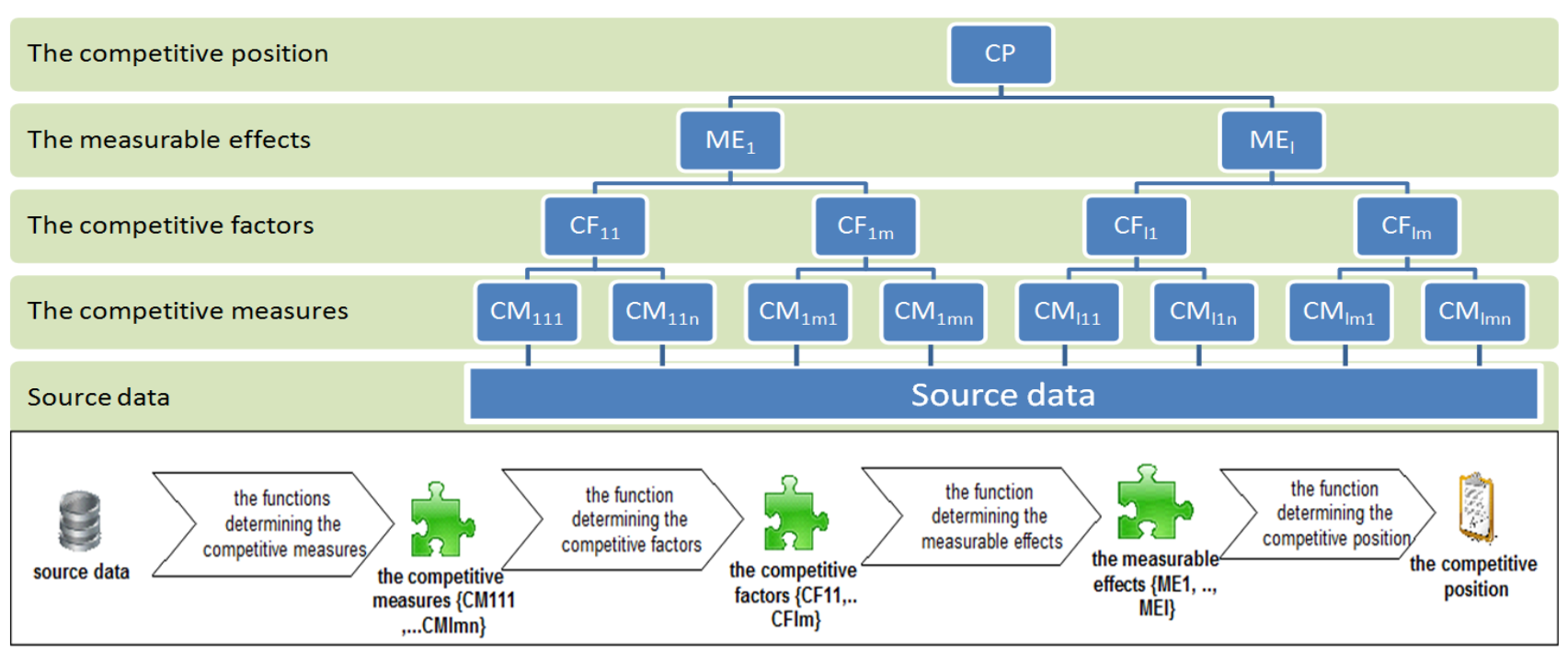

Figure 1. HCAM - Hierarchical Competitiveness Assessment Model (source: own research)

Therefore the research objective is:

RO: To develop a comprehensive tool supporting SMEs in:

- identifying the criteria that are determinants of the company competitiveness;

- developing a strategy that will guarantee the achievement of the assumed competitive position;

- supporting the implementation of all the above items using modern and the most relevant methods and technologies.

After considering the above, the following research hypothesis was formulated:

RH: The method of mutual benchmarking, assuming shared access to the results of the competitive analysis within the group, is the competitive alternative to conventional tools and methods in creating a competitive strategy and providing a sustainable competitive advantage in SMEs.

\section{$3 \quad$ Research methodology}

In order to carry out the proof of the formulated hypothesis and find answers to the defined research question, a two-step research plan was developed, which contained:

- a quantitative research,

- a research experiment.
Quantitative research ${ }^{2}$ (in the form of a direct interview, using the electronic form called CAPI - Computer-Assisted Personal Interviewing) was conducted in a group of Polish dental clinics. The survey sample was selected with a purposely random method among all private dental practises in the SME sector, of which, in 2009, there were 3693 [Walkowska, 2010-2011]. The purposefulness of selection was based on the fact that all the clinics were located in large Polish cities, had computers and belonged to the SME sector. The required sample size for this set was determined by the following assumptions:

- confidence level $(1-\alpha)=95 \%$,

- confidence interval $t=1.96$,

- estimation of the population fraction possessing the analysed characteristic $p=50 \%$,

- estimation of the population fraction not possessing the analysed characteristic $(1-p)=50 \%$,

- the maximum permissible error of measurement $d=$ $8 \%$.

After considering all this, the minimum sample size was set at 150 clinics:

$$
\mathrm{n}=\frac{t^{2} p(1-p)}{d^{2}}=\frac{1,96^{2} * 0,5 * 0,5}{0,08^{2}}=150,0625
$$

The hierarchical competitiveness assessment model (HCAM) was adopted for evaluating the competitiveness in a defined research sample (Błąd! Nie można odnaleźć źródła odwołania., [Rostek, 2012]).

\footnotetext{
2 Scientific work financed by the budget funds for sciences in 2009-2011 as a research project.
} 
Table 1. The structure of the competitive factors in the division of the areas of measurable effects (source: own research)

\begin{tabular}{|c|l|l|l|}
\hline \multicolumn{2}{|c|}{ Measurable effects } & \multicolumn{2}{c|}{ Competitive factors } \\
\hline \multirow{2}{*}{$\mathrm{ME}_{1}$} & \multirow{2}{*}{$\begin{array}{l}\text { modernity and quality of provided medical } \\
\text { services }\end{array}$} & $\mathrm{CF}_{11}$ & technological level \\
\cline { 3 - 4 } $\mathrm{ME}_{2}$ & \multirow{2}{*}{ ability to satisfy the needs of patients } & $\mathrm{CF}_{12}$ & quality of service \\
\hline \multirow{2}{*}{$\mathrm{ME}_{3}$} & \multirow{2}{*}{ achieved sales results } & $\mathrm{CF}_{21}$ & timely realisation of services \\
\cline { 3 - 4 } & & $\mathrm{CF}_{22}$ & lasting relationships with customers \\
\cline { 3 - 4 } & & $\mathrm{CF}_{31}$ & sale \\
\cline { 3 - 4 } & & $\mathrm{CF}_{32}$ & costs and expenses \\
\cline { 3 - 4 } & & $\mathrm{CF}_{33}$ & usage of fixed assets \\
\hline
\end{tabular}

Table 2. The structure of the competitive factors broken down by the competitive measures (source: own research)

\begin{tabular}{|c|c|c|}
\hline Competitive & & Competitive measures \\
\hline \multirow{2}{*}{$\mathrm{CF}_{11}$} & $\mathrm{CM}_{111}$ & the sales of innovative medical services as a $\%$ of the total sales value \\
\hline & $\mathrm{CM}_{112}$ & the costs of investment and development as a $\%$ of the total sales value \\
\hline \multirow{3}{*}{$\mathrm{CF}_{12}$} & $\mathrm{CM}_{121}$ & the number of complaints as a \% of the total number of sold services \\
\hline & $\mathrm{CM}_{122}$ & the value of the complaints as a $\%$ of the total sales value \\
\hline & $\mathrm{CM}_{123}$ & the number of registered patients per one employed medical person \\
\hline \multirow{2}{*}{$\mathrm{CF}_{21}$} & $\mathrm{CM}_{211}$ & the average duration of a visit \\
\hline & $\mathrm{CM}_{212}$ & the average waiting time for a visit \\
\hline \multirow{4}{*}{$\mathrm{CF}_{22}$} & $\mathrm{CM}_{221}$ & $\begin{array}{l}\text { the number of patients using the services of the clinic repeatedly as a } \% \text { of the total } \\
\text { number of patients }\end{array}$ \\
\hline & $\mathrm{CM}_{222}$ & $\begin{array}{l}\text { the number of patients using the services of the clinic permanently as a } \% \text { of the total } \\
\text { number of patients }\end{array}$ \\
\hline & $\mathrm{CM}_{223}$ & $\begin{array}{l}\text { the number of patients from long distance using the services of the clinic as a } \% \text { of the } \\
\text { total number of patients }\end{array}$ \\
\hline & $\mathrm{CM}_{224}$ & $\begin{array}{l}\text { the number of foreign patients using the services of the clinic as a } \% \text { of the total number } \\
\text { of patients }\end{array}$ \\
\hline \multirow{3}{*}{$\mathrm{CF}_{31}$} & $\mathrm{CM}_{311}$ & the number of sold services per one employed medical person \\
\hline & $\mathrm{CM}_{312}$ & the value of sales of medical services per one employed medical person \\
\hline & $\mathrm{CM}_{313}$ & the return on sales \\
\hline \multirow{5}{*}{$\mathrm{CF}_{32}$} & $\mathrm{CM}_{321}$ & the average salary of medical staff \\
\hline & $\mathrm{CM}_{322}$ & the average salary of administrative staff \\
\hline & $\mathrm{CM}_{323}$ & the labour costs of administrative staff as a $\%$ of the labour costs of medical staff \\
\hline & $\mathrm{CM}_{324}$ & the labour costs of medical personnel as a \% of the total value of sales services \\
\hline & $\mathrm{CM}_{325}$ & the costs of promotion and marketing as a $\%$ of the total value of sales services \\
\hline \multirow{2}{*}{$\mathrm{CF}_{33}$} & $\mathrm{CM}_{331}$ & the total value of fixed assets as a $\%$ of the total value of sales services \\
\hline & $\mathrm{CM}_{332}$ & the value of medical equipment as a \% of the total value of sales services \\
\hline \multirow{3}{*}{$\mathrm{CF}_{34}$} & $\mathrm{CM}_{341}$ & the value of medical equipment per one employed medical person \\
\hline & $\mathrm{CM}_{342}$ & the value of profit per one labour hour of medical staff \\
\hline & $\mathrm{CM}_{343}$ & the number of employees subject to any form of training \\
\hline
\end{tabular}


Table 3. The structure of the data source

(source: own research)

\begin{tabular}{|c|c|}
\hline Source data & Description of source data \\
\hline \multicolumn{2}{|c|}{ Data about patients: } \\
\hline LPO & Total number of patients \\
\hline LSP & Number of patients who used the services of the company at least 3 times a year \\
\hline L3L & Number of patients who have been patients for at least 3 years \\
\hline LPZM & Number of patients living more than $50 \mathrm{~km}$ from Warsaw \\
\hline LPZG & Number of foreign patients \\
\hline \multicolumn{2}{|c|}{ Data about sales of services: } \\
\hline SB & Value of gross sales of services in PLN thousands \\
\hline SN & Value of net sales of services in PLN thousands \\
\hline SUN & Gross value of sales of innovative services in PLN thousands \\
\hline $\mathrm{ZS}$ & Profit \\
\hline LWO & Number of visits in the period \\
\hline $\mathrm{SCO}$ & Average patient's wait time for a visit in days \\
\hline SCT & Average duration of a visit in minutes \\
\hline LR & Number of complaints reported by patients \\
\hline WR & Gross value of complaints reported by patients in PLN thousands \\
\hline \multicolumn{2}{|c|}{ Data about employees: } \\
\hline $\mathrm{PO}$ & Total number of employees \\
\hline PM & Number of medical employees \\
\hline PA & Number of administrative personnel \\
\hline PS & Number of workers benefiting from any form of training \\
\hline LRM & Number of man-hours worked by medical personnel \\
\hline LRA & Number of man-hours worked by administrative personnel \\
\hline SPM & Average wage rate of medical personnel \\
\hline SPA & Average wage rate of administrative personnel \\
\hline KRM & Labour cost of medical personnel in PLN thousand \\
\hline KRA & Labour cost of administrative personnel in PLN thousands \\
\hline \multicolumn{2}{|c|}{ Data about costs incurred: } \\
\hline KM & Cost of medical supplies in PLN thousands \\
\hline KN & Costs of inspections and repairs of medical equipment in PLN thousands \\
\hline WS & Value of medical equipment in PLN thousands \\
\hline WZM & Value of stocks of medical supplies in PLN thousands \\
\hline KMR & Marketing and promotion costs in PLN thousands \\
\hline WIR & Investment and development expenditure in PLN thousands \\
\hline CWST & Total value of fixed assets in PLN thousands \\
\hline WB & Value of buildings in PLN thousands \\
\hline
\end{tabular}


The HCAM model contains the following elements:

- the source data - data generated and provided by the companies, which are the results of their activities,

- the competitive measures - source data transformed into a comparable form between the different members of the group; for example, on the basis of the source data of the "total number of clients", the measure of "the number of clients per 1 employ-

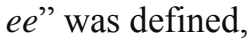

- the competitive factors - the aggregated and normalised value (on the scale of $0-100$ points) of these competitive measures, which belong to the competitive factor,

- the areas of measurable effects - the aggregated value of these competitive factors, which belong to the area of the measurable effects,

- the competitive position - the aggregated value of all areas of the measurable effects.

Its primary purpose was to determine the values of the competitive position of each clinic, based on its activities performance within defined periods of time. The standard method of measuring the competitive position takes into account the value of the identified competitive factors (i.e. criteria that designate areas of competition) and their weights:

$$
\mathrm{fCP}: \mathrm{CP}=\mathrm{l}_{\mathrm{i}=1} \mathrm{CF}_{\mathrm{i}} * \mathrm{w}_{\mathrm{i}}
$$

where:

$\mathrm{CP}=$ value of the competitive position,

$\mathrm{CF}_{\mathrm{i}}=$ value of the $i$-th competitive factor,

$\mathrm{w}_{\mathrm{i}}=$ weight of the $i$-th competitive factor.

Formula (1) indicates that the basis of determining the competitive position is to identify the factors influencing the competitiveness. These are the criteria designated by the key competitive areas, such as: price and quality of the products/services, volume and profitability of sales and staff productivity. To identify the competitive factors of Polish dentist clinics, the results of the quantitative research and the secondary research were obtained (i.e. reports: PKPP Lewiatan ${ }^{3}$ [Starczewska-Krzysztoszek, 2005-2008] and PARP [Żołnierski, 2007-2009; Wilmańska, 2010]). On this basis, eight key factors of competitiveness have been

\footnotetext{
${ }^{3}$ PKPP Lewiatan (pol. Polska Konfederacja Pracodawców Prywatnych Lewiatan ) - Polish Confederation of Private Employers "Lewiatan".

${ }^{4}$ PARP (pol. Polska Agencja Rozwoju Przedsiębiorczości) Polish Agency for Enterprise Development.
}

highlighted, belonging to three groups of measurable effects (Błąd! Nie można odnaleźć źródła odwołania.).

The value of the competitive factors was counted as the aggregate of the competitive measures connected with these factors (Błąd! Nie można odnaleźć źródła odwołania.).

The competitive measures were calculated based on the source data (Błąd! Nie można odnaleźć źródła odwołania.), provided by the users of the HCAM model.

As shown in Błąd! Nie można odnaleźć źródła odwołania., the developed model expands the standard method for determining the competitive position to the sublevels of the competitive measures and the areas of the measurable effects. This is justified by the fact that the competitive measures guarantee the comparability of source data belonging to the differentiated entities, and the measurable effects are shown in the competitive position in the key competitive areas of these entities. The whole is implemented in accordance with the following procedure:

1) At the start the values of individual competitiveness measures $\mathrm{CM}_{\mathrm{ijk}}$ are calculated from the formulas $\mathrm{fCM}_{\mathrm{ijk}}$, associated with each of measure:

$$
\mathrm{CM}_{\mathrm{ijk}} \mathrm{fCM}_{\mathrm{ijk}}: \mathrm{CM}_{\mathrm{ijk}}=\mathrm{f}(\mathrm{DS})
$$

where:

DS - appropriate data source,

$\mathrm{CM}_{\mathrm{ijk}}-k$-th competitiveness measure of $j$-th competitiveness factor in $i$-th measurable effects area,

for example:

$$
\begin{aligned}
& \mathrm{CM}_{123}=\mathrm{LPO} / \mathrm{PM}, \\
& \mathrm{CM}_{342}=\mathrm{ZS} / \mathrm{LRM} .
\end{aligned}
$$

2) On the basis of competitiveness measures are determined values of weighted competitiveness factors:

$$
\mathrm{fCF}_{\mathrm{ij}}: \mathrm{CF}_{\mathrm{ij}}=\mathrm{n}_{\mathrm{k}=1}^{\mathrm{n}} \mathrm{CM}_{\mathrm{ijk}} * \mathrm{w}_{\mathrm{ijk}}
$$

where:

$\mathrm{n}-$ number of competitiveness measures defined for particular competitiveness factor,

$\mathrm{CF}_{\mathrm{ij}}$ - value of $j$-th competitiveness factor in $i$-th measurable effects area,

$\mathrm{CM}_{\mathrm{ijk}}-k$-th competitiveness measure of $j$-th competitiveness factor in $i$-th measurable effects area, 
$\mathrm{w}_{\mathrm{ijk}} \quad$ - weight assigned to competitiveness measure $\mathrm{CM}_{\mathrm{ijk}}$, and the sum of weights $\mathrm{w}_{\mathrm{ijk}}$ designated for each competitiveness factor $\mathrm{CF}_{\mathrm{ij}}$ is 1 :

$$
\mathrm{CF}_{\mathrm{ij}} \quad \stackrel{\mathrm{n}=1}{\mathrm{k}=1} \mathrm{~W}_{\mathrm{ijk}}=1
$$

3) Then competitive measures were aggregated to the value of individual areas of measurable effects $M_{i}$ :

$$
\mathrm{fME}_{\mathrm{i}}: \mathrm{ME}_{\mathrm{i}}=\mathrm{m}_{\mathrm{j}=1} \mathrm{CF}_{\mathrm{ij}} * \mathrm{w}_{\mathrm{ij}}
$$

where:

$\mathrm{m}-$ number of competitiveness factors defined for particular area of measurable effects,

$\mathrm{ME}_{\mathrm{i}}$ - value of $i$-th measurable effects area,

$\mathrm{CF}_{\mathrm{ij}} \quad-j$-th competitiveness factor in $i$-th measurable effects area,

$\mathrm{W}_{\mathrm{ij}}$ - weight assigned to competitiveness factor $\mathrm{CF}_{\mathrm{ij}}$, and the sum of weights $\mathrm{w}_{\mathrm{ij}}$ designated for each measurable effects area $\mathrm{ME}_{\mathrm{i}}$ is 1 :

$$
\mathrm{ME}_{\mathrm{i}} \quad \mathrm{m}_{\mathrm{j}=1} \mathrm{~W}_{\mathrm{ij}}=1
$$

4) Finally on the basis of individual assessments of measurable effects areas has been designated aggregated evaluation as competitive position $\mathrm{CP}$, occupied by each dental clinic in research group:

$$
\mathrm{fCP}: \mathrm{CP}=\mathrm{l}_{\mathrm{i}=1} \mathrm{ME}_{\mathrm{i}} * \mathrm{w}_{\mathrm{i}}
$$

where:

1 - number of areas of measurable effects,

$\mathrm{ME}_{\mathrm{i}}$ - value of $i$-th measurable effects area,

$\mathrm{W}_{\mathrm{i}} \quad$ - weight assigned to $i$-th measurable effects area $\mathrm{ME}_{\mathrm{i}}$, and the sum of weights $\mathrm{w}_{\mathrm{i}}$ for competitive position $\mathrm{CP}$ is 1 :

$$
\mathrm{l}_{\mathrm{i}=1} \mathrm{w}_{\mathrm{i}}=1
$$

The HCAM model has become an initiating element of the research experiment, conducted on a selected group of 10 clinics from 150 covered by the quantitative survey. The aim of the experiment was to evaluate the usefulness of the mutual benchmarking services in the development competitiveness strategies in comparison with the methods and tools currently used in these entities.

The research experiment was carried out in the period from 11-2009 to 06-2010. At that time, clinics were providing the source data for the HCAM model and in return were receiving results of the competitive analysis, like this:

- changes in the results of the HCAM model during the time of each clinic,
- the assessment of the current competitive position in the clinic's group,

- the assessment of the impact of the competitive factors on the competitive position value in the clinic's group,

- the list of activities guaranteeing the assumed value of the competitive position in the clinic's group.

In the case of the results analysis of the HCAM model and determination of the current competitive position of the, each clinic has benefited from statistical data analysis and graphical visualisation of its results. To determine the importance and selection of the competitive factors for the clinic's group the regression method was used. In order to develop a useful sequence of activities ensuring the achievement of the assumed competitive position in the clinic's group, a method of decision trees was used. The whole analysis was implemented and handled by a dedicated BI solution. The results of the obtained research are discussed later in this work.

\section{$4 \quad$ Benchmarking as the competitive analysis method}

The competitiveness of companies is a property that should determine the process of the formulating development strategy [Hitt, et al., 2012]. The measure of competitiveness is a competitive position, calculated as a result of competition from one entity in a group of competitors operating in the same market [Porter, 1998; Giachetti \& Dagnino, 2013]. Therefore the main objective of the strategy of competitiveness development is to provide a plan of action that, with high probability, with well-known constraints and in assumed time, will achieve the expected competitive position.

The effectiveness of the prepared competitiveness strategy depends on knowledge of the competitive factors and the ability to predict the actions taken by the competitors [Trkman, 2010; Zeng, et al., 2010]. The source of the necessary knowledge in this area is undoubtedly the experience and skills of managers, which should be supported by information obtained as a result of the pursued competitive analysis. As confirmed by conducted research [Trkman, et al., 2010, Crough, 2011], those economic entities that take into account the results of the competitive analysis and the existing (market and non-market) constraints have the biggest chance of successful entry and effective activities on the market. 
The above findings show that the achieved competitive position, as a result of the implemented competitive strategy, is constrained not only by business capabilities, but also by the parallel activities carried out by market competitors. Thus, the wider the information regarding the operation of the business and its environment, the greater the effectiveness of the prepared strategy for competitiveness. The competitive analysis usually refers to its own results, but expanded to benchmarking, i.e. the process of comparison analysis in many areas of business with other competitors will increase the management efficiency of the competitiveness development strategy [Dessler, 2004; Huggins, 2010].

The adoption of benchmarking as a method for competitive analysis [Kovačič, 2005; Raharjo, 2010] has resulted in the widening of the scope of its use. The most popular form of benchmarking is an analytical service performed in a defined area of management by the consulting and services companies (for example IBM, ${ }^{5}$ Cartesian ${ }^{6}$ ), which have the data from a specific management area. The strengths of such a service are the high competences of service staff and access to a wide range of necessary data. The drawback, however, is its one-off nature, which is sufficient in the case of projects and undertakings, but becomes a constraint in the case of repetitive actions, such as the continuous projection and implementation of strategies.

In Poland, and across the world, there have been attempts to build and disseminate multi-user solutions in the field of benchmarking analysis [IBIS, 2006; Cooper, et al., 2010]. The strength of these solutions is their durability, openness and accessibility. The drawback, however, is that there are problems with the maintenance, development and flexibility of solutions, upgrades to processing data, and also the interpretation and utility of available results. Hence the new research trend - the knowledge-based benchmarking systems [Lai, et al., 2011] - which in a clear, accessible and useful way supports decision-making and the creation of business strategy. The ability to use these solutions entails the need to implement advanced IT technologies such as BI [Completo, et al., 2012].

Benchmarking, used as a method of competitive analysis, increases the possibility of traditional analysis,

\footnotetext{
${ }^{5}$ http://www-03.ibm.com/systems/services/benchmarkcenter/, date of reading 23-07-2013.

${ }^{6} \mathrm{http}: / /$ www.cartesian.com/technology/technical-services-andconsulting/it-benchmarking, date of reading 23-07-2013.
}

because it not only measures the effects of the strategy, but also identifies causes and points to the possibility of their improvement. Therefore modern benchmarking methods such as the European Benchmarking Procedure [European Commission, 2010; Maggetti \& Gilardi, 2011] or clusters benchmarking [Ketels, 2012; Park, et al., 2012] show how effectively benchmarking can be used to support a competitive strategy.

In the European Union, benchmarking has become a key instrument in the Open Method of Coordination, supporting the achievement of the competitive advantage in member states in terms of both economic and social objectives [Arrowsmith, et al., 2004; Bruno, 2009; European Commission, 2010]. The method is based on mutual learning through the identification and transfer of best practises at different levels of economy management (i.e. sectoral, national and transnational). On this basis, new benchmarking methodologies are created, taking into account the scope, principles and conditions for their implementation [Dévai, et al., 2002; LILAMA, 2010].

Also, the benchmarking of clusters, led by the ESCA (European Secretariat for Cluster Analysis), is found widely used in the European Union. The ESCA has registered 190 clusters and is currently providing the results of a comparative study in the area of organisational structures, processes, products and services [ESCA, 2012]. They also make comparisons on a smaller scale, for example for clusters operating in a specific industry [ABC-Network, 2007; INOVISA, 2012].

The advantage of the presented methods is a wide range of available comparisons and supporting the process of the European institutions. The limitations are the need to involve significant resources and incurring high investment outlays, which require the involvement of government institutions (the European Benchmarking Procedure) or a larger group of cooperating and competing entities (the benchmarking of clusters). In this context, one can see the need for such an implementation of a benchmarking method, which will be more accessible and flexible for SMEs, which function primarily in the local market, have only a little knowledge and experience in the field of European cooperation and remain outside the existing clusters. The proposed solution is the mutual benchmarking method. 


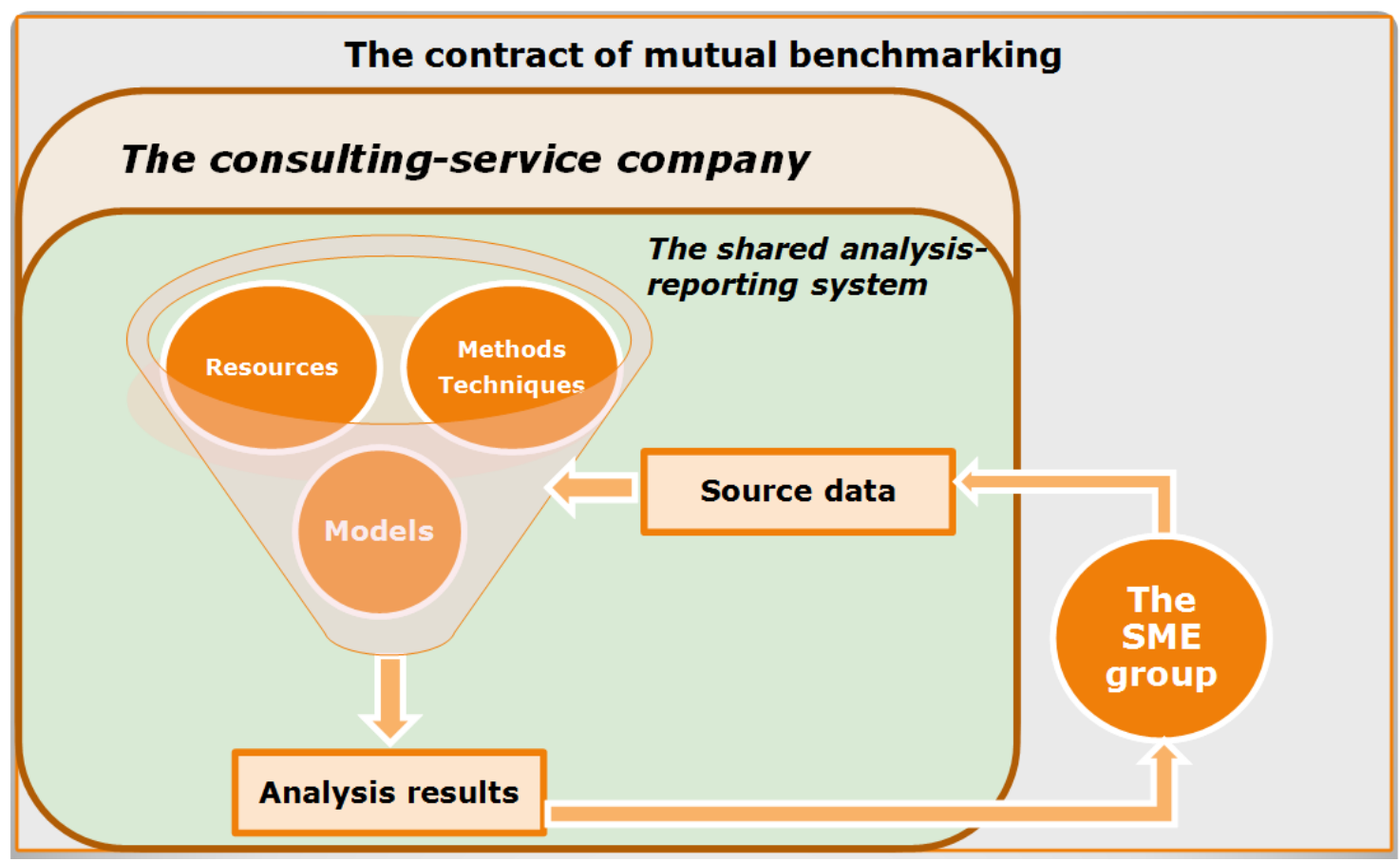

Figure 2. Mutual benchmarking method (source: own research)

\section{$5 \quad$ Mutual benchmarking method for SMEs}

Preparing of a competitiveness strategy in a typical Polish SME company is to collect the available results of its performance, preparing them in the form of simple statistical summaries and charts, and on this basis make strategic decisions. This mode of decisionmaking takes into account only the prospect of their own business, with a very general knowledge of the market and the actions taken by competitors. While a company's competitiveness is conditioned by this which products/services and their attributes (like: quality, modernity, diversity, price, availability, delivery time, warranty, specials, discounts) offer in comparison with competitors existing in the common market. This means that the adoption of an appropriate strategy, which guarantees the achievement of competitive advantage, involves the selection of a portfolio of these criteria, within which the company wants to compete.

The development of an appropriate strategy requires access to information on the needs and expectations of the customer market and the possibility of competitors (manufacturer market), as well as the support due to the timing of the decisions and the size of the processed data. Reaching the information coming from the environment and effective (competitive) supporting tools is usually beyond the reach of a single SME com- pany. Therefore, a collaboration remains, resulting in synergies, enabling a more complete and efficient (than would be possible individually) access to information, more accurate choice of strategy and making management decisions.

This collaboration has been included in the definition of mutual benchmarking, understood as to implement shared competitive analysis, as a result of which every group member receives information about the possibilities of effective ways to compete in this market area, which has been designated by the data set provided by the network members.

In this context the mutual benchmarking method (Figure 2) guarantees the proper organisation of companies' collaboration and realisation of competitive analysis. It is necessary to use the most suitable analytical methods, models, tools, technology and data in order to build an analysis-reporting solution. This will ensure it correct functioning and development throughout the life cycle.

While the group of SMEs would be able to run such an IT solution through a network collaboration, it would be difficult for them to keep it running in the long term due to the lack of qualified personnel. 


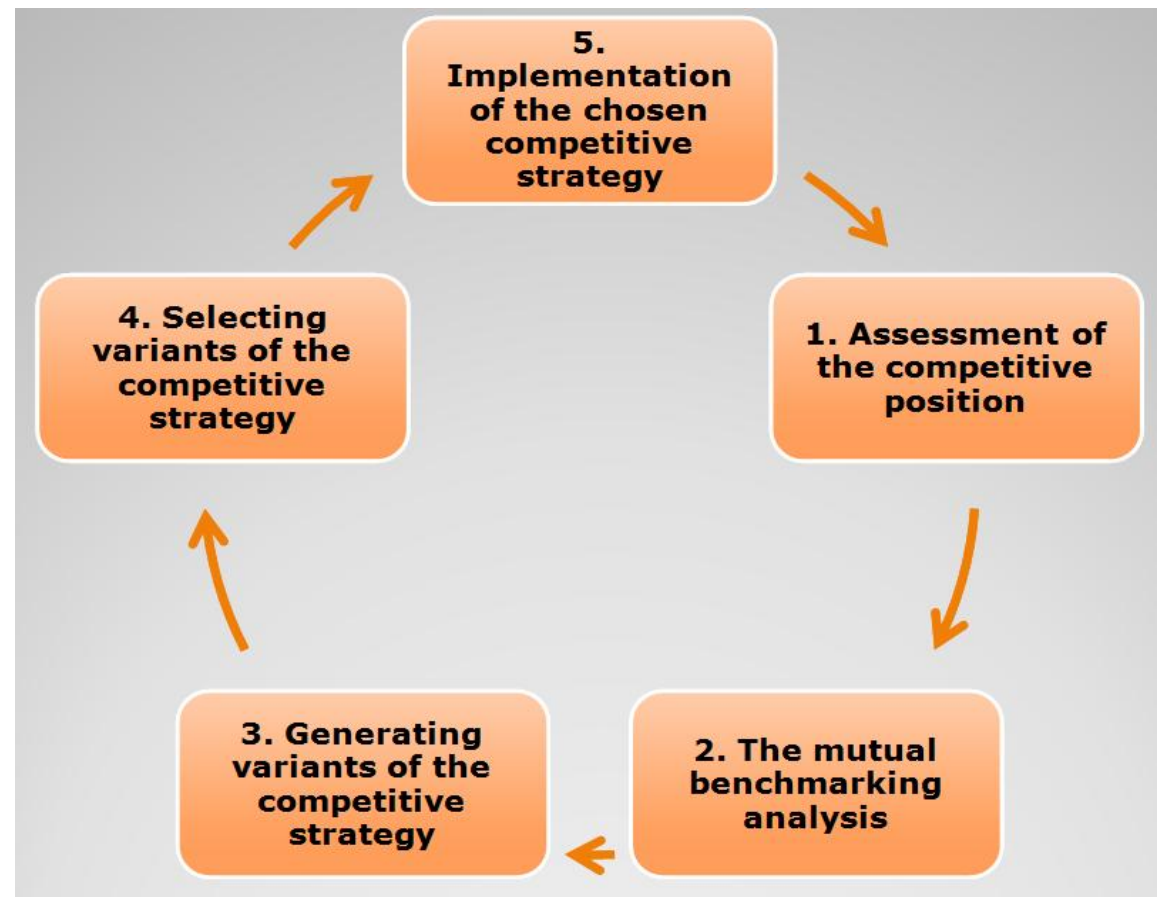

Figure 3. The life cycle of the competitive strategy in the mutual benchmarking method (source: own research)

For this reason, participation of an external company is necessary, which would provide continuity and functioning coordination and a full mutual benchmarking service. The proposed method (Figure 2) integrates several elements, which hitherto have been implemented independently:

- it provides knowledge of the suggested actions for the competitive strategy with a known level of effectiveness, and not exclusively statistical results of competitive analysis;

- it enables the use of advanced information technologies that are not available or cannot be used by a single SME company;

- it strengthens the analytical potential of source data by integrating the resources of multiple SME companies;

- it teaches entrepreneurs the posture of competitive cooperation in place of rivalry;

- it is a flexible form of collaboration in which the company takes the decision to join or leave the group.

The key in the implementation of the mutual benchmarking method involves a consulting-services company, responsible for the design, organisation and implementation of competitive analysis, and for providing the results in a shape and form useful to the end-user. The consulting-services company is responsible for coordinating and monitoring the realisation of mutual benchmarking method to ensure the best its execution, expected by the participants. This expected benefit is the high efficiency of the implemented competitive strategy, as measured by the achieved competitive position. The sequence of operations making up the cycle of creating a competitive strategy in the mutual benchmarking method is presented in Figure 3.

Assessment of the competitive position requires (Figure 3, step 1): knowledge of the set of criteria having a determining impact on competitiveness, skills measuring their value and their aggregated assessment as the competitive position. Such activities are realised by using a defined HCAM model, as described in Section 3.

The mutual benchmarking analysis (Figure 3, step 2) enables the company to compare its own results, obtained from the HCAM model, with similar results obtained by the competitors. This step is particularly precious for the company because of the opportunity to learn by patterns applied and tested by competitors. Based on the results of step 1 and 2 and the current capabilities and needs of the company, possible variants of the competitive strategy are established (Figure 3 , step 3). 


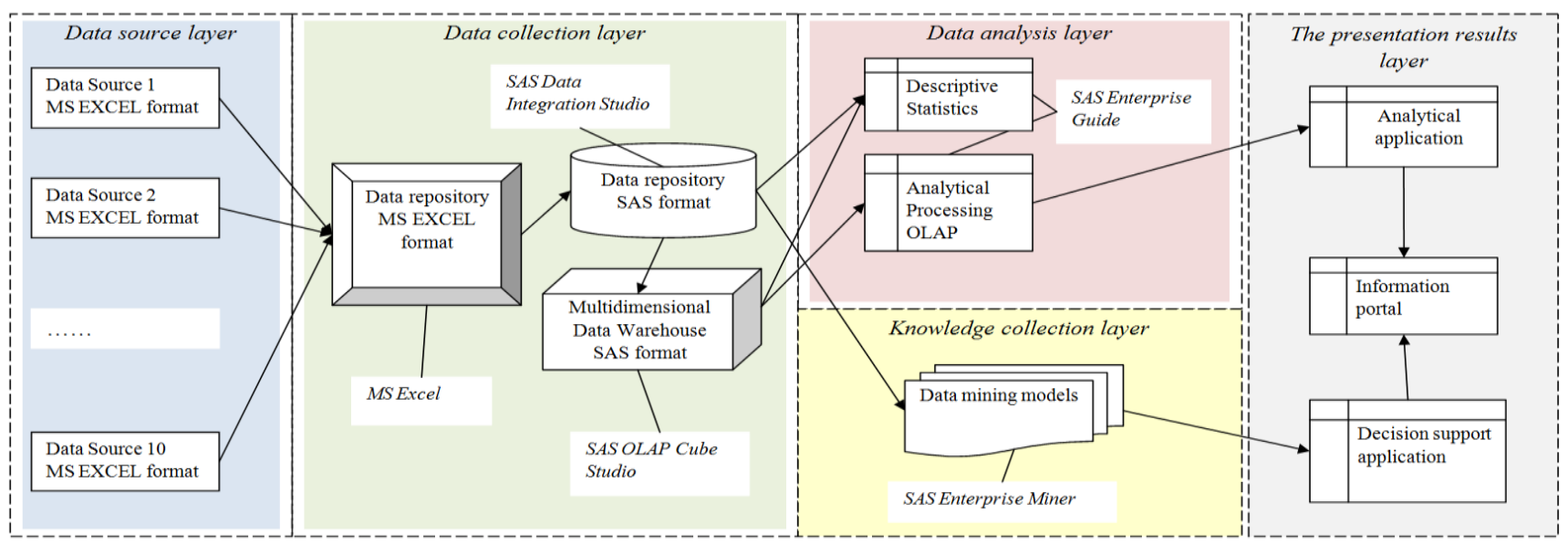

Figure 4. The dedicated Business Intelligence system

(source: own research)

These variants, understood as a sequence of actions, the implementation of which ensures achievement of a certain competitive position, can be generated by the decision-maker on his own, but can also be supported by advanced analytical methods and technology, which is provided by the mutual benchmarking method and which is presented in the next section.

From the set of obtained solutions this variant of strategies that is optimal for the company at a given time and with known conditions and constraints must be selected (Figure 3, step 4). This step can also be performed manually by the decision-maker or automated by a specialised IT tool (as illustrated in the next section).

Step 5 (Figure 3), closing the life cycle of the competitive strategy, implements the chosen strategy variant. However, the assessment of its results will only be possible in the next iteration of the cycle, based on a new set of results of the HCAM model (Figure 3, step 1) and relating them to the results achieved at the same time by its competitors (Figure 3, step 2). An example of using the mutual benchmarking method in the group of Polish SME enterprises is presented in the next section.

\section{The case study of using the mutual bench- marking method}

Verification of the usefulness and effectiveness of the mutual benchmarking method was conducted within the research programme described in Section 3.

A characteristic feature of the selected research group was management-based intuition and their own experience resulting in highly variable financial performance (a few clinics, potential participants in the research experiment, still announced their bankruptcy during its organisation).

Typical analyses used by these clinics to support strategic decisions are statistical reports of the achieved results and variants of simulation scenarios generated in an MS Excel spreadsheet (used especially in the case of investment decisions). The clinics had no knowledge of results obtained at the same time by their market competitors. Their effectiveness was measured by the financial results achieved, but in most cases they were not able to answer the question about which areas of their business are potential sources of competitive advantage (except for dental clinics providing custom services in unique technology). Neither could they determine which areas depart significantly from what the competition has and what it offers. So their decisions were mostly intuitive, very cautious and focused solely on survival; also the uncertainty degree and involved risk were very high. Competitive advantage achieved in this way is purely a matter of chance and it is difficult to ensure its stability over time.

Despite this situation, only a part of the group (about $35 \%$ of the 150 surveyed clinics) was aware of the fact that the low efficiency of their management was the result of a lack of information supporting decisionmaking. Among this group, 10 entities were selected that participated in the research experiment, using the services of mutual benchmarking to improve their competitive position and achieved results. The data supplying the HCAM model were these, that matched the requirements of the model and were also collected, processed and analysed every day in these clinics. All it was performed through a dedicated Business Intelligence System (Figure 4). 
Table 4. Selection of the competitive factors - the regression analysis results (source: own research)

\begin{tabular}{|c|c|c|c|c|c|}
\hline Parameter name & Freedom degrees & Parameter value & Error value & $\boldsymbol{t}$ & $\boldsymbol{p}$ \\
\hline Intercept & 1 & 0.2952 & 0.57440 & 0.51 & 0.6103 \\
\hline $\mathrm{CF}_{11}$ & 1 & 0.1658 & 0.00294 & 56.41 & $<.0001$ \\
\hline $\mathrm{CF}_{12}$ & 1 & 0.1633 & 0.00316 & 51.74 & $<.0001$ \\
\hline $\mathrm{CF}_{21}$ & 1 & 0.1644 & 0.00303 & 54.24 & $<.0001$ \\
\hline $\mathrm{CF}_{22}$ & 1 & 0.1655 & 0.00226 & 73.16 & $<.0001$ \\
\hline $\mathrm{CF}_{31}$ & 1 & 0.0932 & 0.00333 & 27.97 & $<.0001$ \\
\hline $\mathrm{CF}_{32}$ & 1 & 0.0637 & 0.00209 & 30.49 & $<.0001$ \\
\hline $\mathrm{CF}_{33}$ & 1 & 0.0693 & 0.00233 & 29.77 & $<.0001$ \\
\hline $\mathrm{CF}_{34}$ & 1 & 0.0980 & 0.00240 & 40.83 & $<.0001$ \\
\hline
\end{tabular}

These data collected from all the participants in the experiment and placed in the HCAM model enabled the resulting data set to be obtained, and this was the basis for the mutual benchmarking competitive analysis.

Clinic W08 was initially the leader of the group with the highest value of the competitive position CP (56 points at 100 points max). However, the problem of this clinic was relatively low sales turnover and high costs of services, which was used by clinic W10 to become the leader of the next period (47 points at 100 max.). In response, clinic W08 (43 points at that time) decided to use the results of the analyses developed in the framework of mutual benchmarking services, formulating the following analytical question:

Do all the competitive factors identified in the HCAM model currently have an equal impact on the value of the competitive position?

The past experience of participants indicated that the strength of this impact is unequal and variable over time. In order to prove this hypothesis, the regression model was constructed with the $\mathrm{CP}$ as the dependent variable and the competitive factors as the independent variables:

$$
\begin{aligned}
\mathrm{CP}= & \mathrm{CF}_{11} * \mathrm{w}_{11}+\mathrm{CF}_{12} * \mathrm{w}_{12}+\mathrm{CF}_{21} * \mathrm{w}_{21}+ \\
& \mathrm{CF}_{22} * \mathrm{w}_{22}+\mathrm{CF}_{31} * \mathrm{w}_{31}+\mathrm{CF}_{32} * \mathrm{w}_{32}+ \\
& \mathrm{CF}_{33} * \mathrm{w}_{33}+\mathrm{CF}_{34} * \mathrm{w}_{34}+\varepsilon
\end{aligned}
$$

where:

$\mathrm{CP}=$ the dependent variable - the value of the competitive position,

$\mathrm{CF}_{\mathrm{ij}}=$ the independent variable - the value of the $i j$ th competitive factor, $\mathrm{w}_{\mathrm{ij}}=$ the model parameter - the weight assigned to the $i j$ th competitive factor,

$\varepsilon \quad=$ the model error - the intercept.

Choosing the IT solution in the Business Intelligence technology, developed in the framework of mutual benchmarking services, made it possible to use advanced data mining tools that aren't known and used in the SME sector. The advantage of using an advanced analytical solution was the ability to test many different variants of regression analysis and the selection of these was characterised by the lowest validation error. The following variants of regression analysis were examined:

- linear regression with a progressive method of estimation of the model parameters,

- linear regression with a backward method of estimation of the model parameters,

- linear regression with a stepwise method of estimation of the model parameters,

- regression with the iterative LARS (Least Angle Regression) method of estimation of the model parameter,

- regression with estimation of the model parameters using the PLS method (Partial Least Squares),

- two-stage method of regression.

The best results were obtained by(f@s)ing a two-stage regression analysis. The model proved to be significant $(F=3561.88 ; p<0.0001)$. Predictors explained together $99 \%$ of the dependent variable $\left(R^{2}=0.9988\right)$. Detailed results of the estimation of the model parameters are presented in Table 4. 


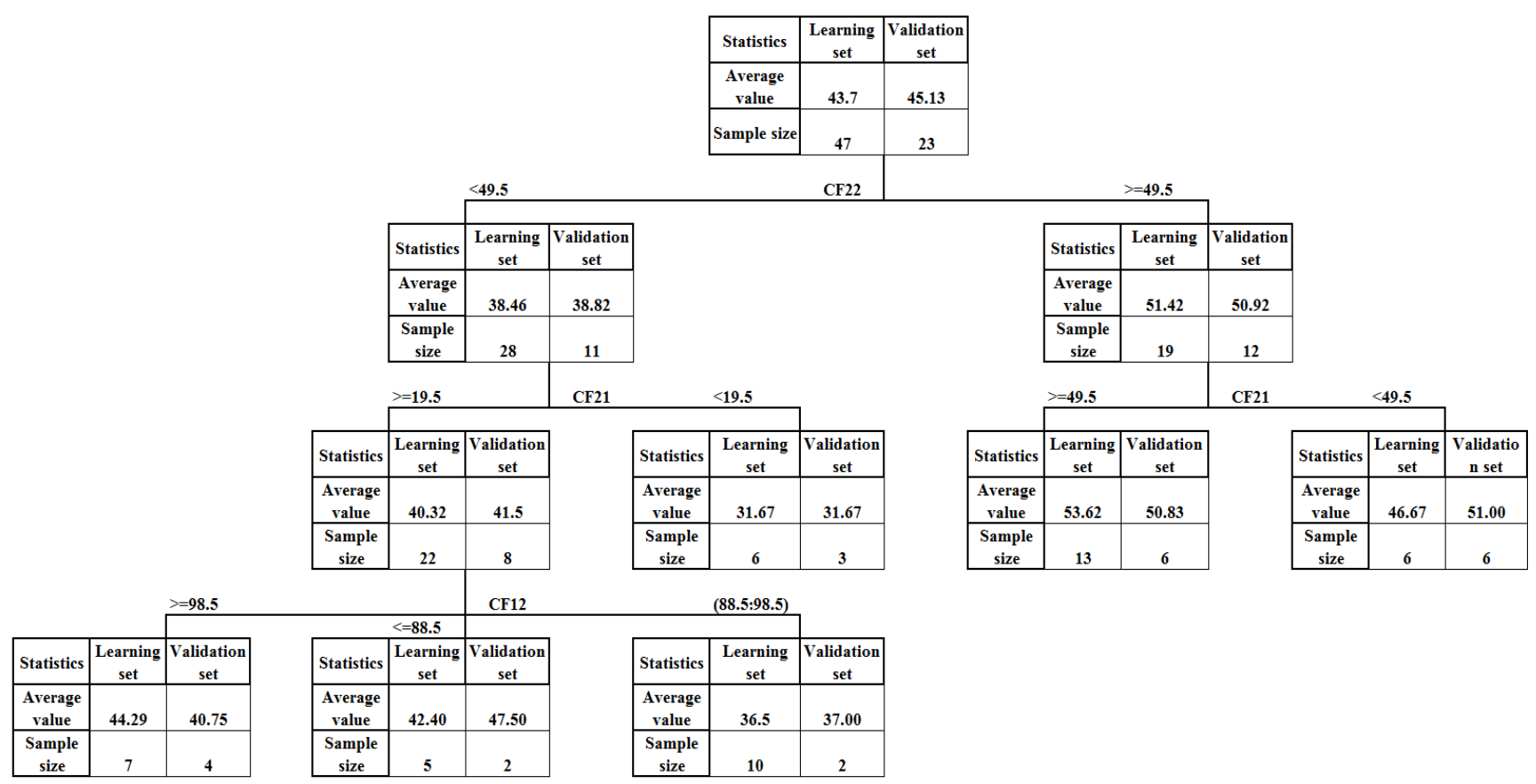

Figure 5. The suggested strategic actions - the results of decision tree analysis (source: own research)

As shown in Table 4, all the independent variables are important for the model results, which confirms the validity of their identification and selection in the HCAM model. However, during the realisation of the research experiment the greatest impact on the value of the $\mathrm{CP}$ had variables: $\mathrm{CF}_{11}$ (technological level), $\mathrm{CF}_{12}$ (quality of service), $\mathrm{CF}_{21}$ (timely realisation of services), $\mathrm{CF}_{22}$ (lasting relationships with customers). These are the competitive factors belonging to two areas of the measurable effects: $\mathrm{ME}_{1}$ (modernity and quality of provided medical services) and $\mathrm{ME}_{2}$ (ability to satisfy the needs of patients).

Knowing which competitive factors have a particular impact on the value of the competitive position, the W08 clinic formulated the next analytical question:

\section{In what range should the values of the identified com-} petitive factors be changed in order to be able to achieve the assumed competitive position?

In order to find answers to this research question, an analysis was performed using decision trees, wherein the independent variables adopted for analysis were only those competitive factors that were identified in the regression analysis as the most important because of the change in the $\mathrm{CP}$ value, i.e.: $\mathrm{CF}_{11}$ (technological level), $\mathrm{CF}_{12}$ (quality of service), $\mathrm{CF}_{21}$ (timely realisation of services) and $\mathrm{CF}_{22}$ (lasting relationships with cus- tomers). The dependent variable was still the $\mathrm{CP}$ value. The results obtained are presented in Figure 5.

The results of decision tree analysis showed (Figure 5) that the value of the $\mathrm{CP}$ at the average level of 51 points (at 100 points max.) primarily impacts on the value of $\mathrm{CF}_{22}$ (lasting relationships with customers), exceeding 49.5 points (at 100 points max.). If a clinic wants to achieve a higher than average $\mathrm{CP}$ value, it should also take care to preserve the value of factor $\mathrm{CF}_{21}$ (timely realisation of services) at a level above 49.5 points (at 100 points max.).

Each clinic participating in the research experiment received the results of all these analyses. Clinics W08 and W10 also benefited from them. Apart from that W08 had treated these results comprehensively and concluded that the maintenance of high value of $\mathrm{CF}_{21}$ and $\mathrm{CF}_{22}$ may not be enough if other participants proceeded in the same way. Therefore it also ensured sufficiently high values for factors $\mathrm{CF}_{11}$ and $\mathrm{CF}_{12}$, which clinic $\mathrm{W} 10$ did not do. The consequence of these proceedings W08 has returned to the position of group leader (with 58 points) and W10 has lost this position (with 42 points).

The results obtained from the research experiment showed that the use of the mutual benchmarking method is an alternative and an effective tool in the development of competition in the SME sector. 
It has a substantial impact on reducing the uncertainty in the process of making strategic decisions. It also strengthens the competitive potential of recipients to a level that ensures the feasibility of the competitive analysis implementation to the same level as in the large enterprises. The final effectiveness of the method is however strongly determined by the way and extent of using the obtained information and knowledge. And this is conditioned by knowledge, experience and belief in the value and importance of competitive analysis by decision-makers.

\section{$7 \quad$ Summary}

In implementing the main aim of the research, the mutual benchmarking method was developed and presented as an alternative to traditional methods and tools of competitiveness management in the SME sector. Noticing the limitations in the availability of the resources, funds and tools required to implement competitive analysis, as part of this method an organisation for reporting and analysis a solution is proposed, dedicated to supporting the competitive development strategy for defined groups of users. The availability of this solution for enterprises with reduced financial, human and organisational capabilities is provided by delivering it in the form of a complete service.

The mutual benchmarking service supports the creation of a competitive strategy in the enterprises in terms of developing a competitive assessment model and dedicated IT solution, providing technical and organisational conditions for their implementation, delivering the solution in the form of flexible services and matching available information to the needs and capabilities of the user. The research experiment performed in the aspect of the utility of this method and the defined research hypothesis showed that although the acquired information is useful for managing the development of competitiveness, the effectiveness of its use depends on the actions taken (or omitted) by the decisionmaker.

During the experiment the great meaning of the whole process of quality, quantity, detail and form of information provided to the user was observed also. This in turn determines the need for a very precise definition of the scope of the functioning of a dedicated IT solution, and above all, the form and details of the information exchanged with the user.
Benchmarking as a method to learn from the best provides the most knowledge of the competitive development strategy for those organisations that are in a lower competitive position. The organisations with a higher level of competitiveness acquire in this way the knowledge of potential risks posed by competitors, which in turn prepares them to prepare for the identified threats. This moment in which the mutual benchmarking service stops to provide new useful knowledge for its members compensates the competitive level in the whole group. When all the participants achieve a similar level of competitiveness, the group should expand the number of members by admitting new organisations or be terminated. Even then it can still take advantage and gain an advantage over its competitors, thanks to the knowledge gained through the mutual benchmarking service. In this way the mutual benchmarking method becomes a tool for knowledge transfer about effective competitive activities, which contributes to the development of method participants, but also to their immediate environment.

On this basis it should be noted that the method of benchmarking is a new form of an effective mutual support competitive strategy, which compensates the differences in access to information and knowledge for SMEs. It also has the advantage of promoting a new meaning of competitiveness, understood as competitive collaboration instead of competitive rivalry. This collaboration does not mean giving up on putting the goals of its enterprise first, but using the whole group opportunities. And in this sense it is also a new research area for supporting the development of competitiveness in the SME sector.

\section{$8 \quad$ References}

[1] ABC-NETWORK (2007) Benchmarking study. Deliverable No. 6. Network of European AgroBiotech Clusters, EUROPE INNOVA, European Commission.

[2] Ajitabh A., \& Momaya K. (2004) - Competitiveness of firms: review of theory, frameworks, and models. Singapore Management Review, Vol. 26, No. 1, pp. 45-61.

[3] Arrowsmith J., Sisson K., Marginson P. (2004) What can 'benchmarking' offer the open method of co-ordination?, Journal of European Public Policy, No. 11, Vol. 2, April 2004, Taylor \& Francis Ltd, pp. 311-328. 
[4] Balkyte A., \& Tvaronavičiene M. (2010) - Perception of competitiveness in the context of sustainable development: facets of "Sustainable competitiveness". Journal of Business Economics and Management, 11(2), pp. 341-365.

[5] Begg I. (1999) - Cities and competitiveness. Urban studies, No. 36(5-6), pp. 795-809.

[6] Benchmarking Code of Conduc (2010), Global Benchmarking Network, Berlin.

[7] Bernal S.M.H., Burr C. \& Johnsen R.E. (2002). Competitor networks: international competitiveness through collaboration: The case of small freight forwarders in the High-Tech Forwarder Network. International Journal of Entrepreneurial Behaviour \& Research, 8(5), pp. 239-253.

[8] Bilińska-Reformat K. (2011) - "Marketing Audit of a Young Enterprise” project as a diagnostic tool of marketing activities of small and medium sized enterprises - empirical approach. Research Papers of Wrocław University of Economics (237/2011), pp. 315-325.

[9] Brandenburger Adam M. \& Barry J. Nalebuff (1998) - Co-opetition: A revolutionary mindset that combines competition and co-operation. New York: Currency Doubleday.

[10] Bruno I. (2009) - The indefinite discipline of competitiveness benchmarking as a neoliberal technology of government. Minerva, 47(3), pp. 261-280.

[11] Cellino R. \& Soci A. (2012) - Pop competitiveness. PSL Quarterly Review, 55(220), pp. 71-101.

[12] Completo J., Cruz R.S., Coheur L. \& Delgado, M. (2012) - Design and Implementation of a Data Warehouse for Benchmarking in Clinical Rehabilitation. Procedia Technology, 5, pp. 885-894.

[13] Cooper, B.F., Silberstein A., Tam E., Ramakrishnan, R. \& Sears R. (2010, June) - Benchmarking cloud serving systems with YCSB. In Proceedings of the 1st ACM symposium on Cloud computing (pp. 143-154). ACM.

[14] Crouch G.I. (2011) - Destination competitiveness: an analysis of determinant attributes. Journal of Travel Research, 50(1), pp. 27-45.

[15] D'Aveni R.A. (2010) - Beating the commodity trap: How to maximize your competitive position and increase your pricing power. Harvard Business Press.

[16] Dessler G. (2004) - Management. Principles and Practices for Tomorrow's Leaders. Pearson Prentice Hall, New Jersey.

[17] Dévai K., Papanek G., Borsi B. (2002) - A methodology for benchmarking RTD organisations in Central and Eastern Europe. Budapest University of Technology and Economics, Budapest.

[18] Dziekoński K. (2011) - Projects in Innovative Small and Medium Enterprises. Economy and Management, No. 4(2011), pp. 125-134.
[19] ESCA (2012) - Benchmarking as a tool of Cluster Analysis. Cluster excellence makes the difference, European Secretariat of Cluster Analysis, Berlin.

[20] European Commission (2012) - Customs 2013 Programme Benchmarking Guide, European Commission, Brussels.

[21] Feurer R., Chaharbaghi K., (1994) - Defining Competitiveness: A Holistic Approach. Management Decision, Vol. 32, No. 2, pp. 49-58.

[22] Garengo P., Biazzo S., Bitici U.S. (2005) - Performance measurement systems in SMEs: a review for a research agenda [in] International Journal of Management Reviews. Vol. 7, No. 1, pp. 25-47.

[23] Giachetti C. \& Dagnino G.B. (2013) - Detecting the relationship between competitive intensity and firm product line length: Evidence from the worldwide mobile phone industry. Strategic Management Journal.

[24] Gunday G., Ulusoy G., Kilic K. \& Alpkan L. (2011) - Effects of innovation types on firm performance. International Journal of Production Economics, 133(2), pp. 662-676.

[25] Hitt M.A., Ireland R.D. \& Hoskisson R.E. (2012) Strategic Management Cases: Competitiveness and Globalization. $10^{\text {th }}$ edition. Cengage Learning, South Western.

[26] Huggins R. (2010) - Regional competitive intelligence: benchmarking and policy-making. Regional Studies, 44(5), pp. 639-658.

[27] IBIS, 2006, URL:

http://help.procureweb.ac.uk/goodpracticeguide/10 57model_masterlist/1046ibis/ index.html, reading date 2013-07-23.

[28] INOVISA (2012) - International benchmarking study of competitiveness poles and clusters and identification of best practices. The Cluster Agro-Industrial, Ribatejo, Portugal.

[29] Ketels C., Lindqvist G. \& Sölvell Ö. (2012) Strengthening Clusters and Competitiveness in Europe. Stocholm School of Economics.

[30] Kingsley G. \& Malecki E.J. (2004) - Networking for competitiveness. Small Business Economics, 23(1), pp. 71-84.

[31] Kovačič A. (2005) - Competitiveness as a source of development. Working Paper, Inštitut za Ekonomska Raziskovanja, No. 28 (2005), Ljubljana.

[32] Lai M.C., Huang H.C. \& Wang W.K. (2011) - Designing a knowledge-based system for benchmarking: A DEA approach. Knowledge-Based Systems, 24(5), pp. 662-671.

[33] Lee S., Park G., Yoon B. \& Park J. (2010) - Open innovation in SMEs - An intermediated network model. Research Policy, 39(2), pp. 290-300. 
[34] LILAMA (2010) - Observatory of Good Practices. Benchmarking Method Guide, The Lilama Network, European Commission.

[35] Maggetti M. \& Gilardi F. (2011) - The policymaking structure of European regulatory networks and the domestic adoption of standards. Journal of European Public Policy, 18(6), pp. 830-847.

[36] Magretta J. (2011) - Understanding Michael Porter: The Essential Guide to Competition and Strategy. Harvard Business Review Press, Cambridge.

[37] Malecki E.J. \& Tootle D.M. (1996) - The role of networks in small firm competitiveness. International Journal of Technology Management, 11(12), pp. 1-2.

[38] Moon H.Ch., Newman S.P. (1995) - Competitiveness of product, firm, industry, and nation in a global business, International Business Journal, Vol. 5, No. 1, pp. 37-43.

[39] Park Y.W., Amano T. \& Moon G. (2012) - Benchmarking open and cluster innovation: case of Korea. Benchmarking: An International Journal, 19(4/5), pp. 517-531.

[40] Pettigrew A.M. (1988) - Competitiveness and the Management Process. Basil Blackwell, New York.

[41] Porter M.E. (1980) - Competitive Strategy: Techniques for Analyzing Industries and Competitors, The Free Press, New York.

[42] Porter M.E. (1985) - Competitive Advantage: Creating and Sustaining Superior Performance. Collier Macmillan, London.

[43] Porter M.E. (1998) - Competitive Strategy: Techniques for Analyzing Industries and Competitors, Free Press, New York.

[44] Porter M.E. (2008). Competitive advantage: Creating and sustaining superior performance. SimonandSchuster.com.

[45] Porter M.E. (2011) - Competitive advantage of nations: creating and sustaining superior performance. Simon and Schuster.

[46] Raharjo H., Chai K.H., Xie M. \& Brombacher A.C. (2010) - Dynamic benchmarking methodology for quality function deployment. Benchmarking: An International Journal, 17(1), pp. 27-43.

[47] Rosenfeld S.A. (1996) - Does cooperation enhance competitiveness? Assessing the impacts of interfirm collaboration. Research Policy, 25(2), pp. 247-263.

[48] Rostek K. (2010) - Business Intelligence for SME [in] SMEs and Entrepreneurship (Lechman E. ed.), Vol. II, Gdańsk University of Technology Publishing House, Gdańsk, pp. 164-190.
[49] Rostek K. (2012) - The reference model of competitiveness factors for SME medical sector [in] Economic Modelling, 29 (2012), pp. 2039-2048, Elsevier.

[50] Starczewska-Krzysztoszek M. (2005) - Badanie konkurencyjności sektora MŚP. Raport z badań. PKPP Lewiatan, Warszawa.

[51] Starczewska-Krzysztoszek M. (2006) - Konkurencyjność Matych i Średnich Przedsiębiorstw 2006. Raport z badań. PKPP Lewiatan, Warszawa.

[52] Starczewska-Krzysztoszek M. (2007) - Konkurencyjność sektora MŚP. Raport z badań. PKPP Lewiatan, Warszawa.

[53] Starczewska-Krzysztoszek M. (2008a), Konkurencyjność sektora MŚP 2008. Wyniki badania. PKPP Lewiatan, Warszawa.

[54] Starczewska-Krzysztoszek M. (2008b) - Monitoring kondycji sektora MŚP 2008. PKPP Lewiatan, Warszawa.

[55] The European Benchmarking Code of Conduct (2009) - European Foundation for Quality Management, Brussels.

[56] Trkman P. (2010) - The critical success factors of business process management. International Journal of Information Management, 30(2), pp. 125-134.

[57] Trkman P., McCormack K., De Oliveira M.P.V. \& Ladeira M.B. (2010) - The impact of business analytics on supply chain performance. Decision Support Systems, 49(3), pp. 318-327.

[58] Walkowska K. (red.) (2010) - Działalność przedsiębiorstw niefinansowych w 2008 roku. Główny Urząd Statystyczny, Warszawa.

[59] Walkowska K. (red.) (2011) - Działalność przedsiębiorstw niefinansowych w 2009 roku. Główny Urząd Statystyczny, Warszawa.

[60] Wilmańska A. (2010) - Raport o stanie sektora malych $i$ średnich przedsiębiorstw $w$ Polsce $w$ latach 2008-2009. PARP, Warszawa.

[61] Zeng S.X., Xie X.M. \& Tam C.M. (2010) - Relationship between cooperation networks and innovation performance of SMEs. Technovation, 30(3), pp. 181-194.

[62] Żołnierski A. (red.) (2009) Raport o stanie sektora matych i średnich przedsiębiorstw $w$ Polsce $w$ latach 2007-2008, PARP, Warszawa.

[63] Żołnierski A., Pyciński S. (red.) (2007) - Raport o stanie sektora matych $i$ średnich przedsiębiorstw w Polsce w latach 2005-2006, PARP, Warszawa.

[64] Żołnierski A., Zadura-Lichota P. (red.) (2008) Raport o stanie sektora matych i średnich przedsiębiorstw w Polsce w latach 2006-2007. PARP, Warszawa. 